\title{
Liturgical singing as ritual symbol
}

\author{
Author: \\ Coenie Calitz ${ }^{1}$ \\ Affiliation: \\ ${ }^{1}$ Department of Practical \\ Theology, Faculty of \\ Theology, University of \\ Pretoria, South Africa \\ Correspondence to: \\ Coenie Calitz \\ Email: \\ cjcalitz@lantic.net \\ Postal address: \\ PO Box 5539, Kockspark \\ 2523, South Africa \\ Dates: \\ Received: 01 Sept. 2010 \\ Accepted: 05 May 2011 \\ Published: 17 Aug. 2011 \\ How to cite this article: \\ Calitz, C., 2011, 'Liturgical \\ singing as ritual symbol', \\ Verbum et Ecclesia 32(1), Art. \\ \#430, 7 pages. doi:10.4102/ \\ ve.v32i1.430 \\ Note: \\ This article is based on a PhD \\ thesis with Prof. C.J.A. Vos \\ (supervisor) and Prof. H.J.C. \\ Pieterse (co-supervisor).
}

Liturgical singing is more than text and melody; it is also symbol and ritual. It is part of the ensemble of rituals within the worship service. As a ritual symbol, it is closely connected to the culture or subculture where it is conducted. Meaning is not only immanent in the text (lyrics), but assigned on a continuous base and differs from culture to culture. As a ritual symbol, liturgical singing does not only point to another reality, but presents the other reality within the cultural context of the worship service; within ritual the music and melody are more important than text and lyrics. Liturgical singing as a ritual symbol is never static, but in a continuous process of change.

\section{Introduction}

Singing is part of the worship service; one can hardly imagine a worship service without singing and music. But why do congregations sing and what do they sing? Is singing only text (lyrics) set to melody? Can the outcome of liturgical singing be predicted by adding the meaning of the words to the effect of the melody? Is a good liturgical song only a combination of theologically sound words with an appropriate melody? In this article, it is argued that a liturgical song is more than text and melody. The meaning of a song is not only immanent in the text or words. Meaning is also attributed by the congregation who sings the song; often by ritualising the song. A given song could also have a symbolic and ritual meaning, which could differ from congregation to congregation.

This article is explorative; it is not aimed at understanding the whole act and process of liturgical singing. It is therefore not linguistic or musicological in its approach; rather, it aims at exploring and understanding liturgical singing from the perspective of ritual and symbol.

\section{Rituals}

Müller (1990:111, cf. 1987:35; Barnard 2000:5) notes that liturgy belongs to the context of rites and rituals. Rituals are part of day-to-day life. They are more than repeated actions. Rituals are closely connected to culture (or subcultures) and give expression to common identity (Vos \& Pieterse 1997:121). They are closely linked to the social processes within a given community or congregation (Vos \& Pieterse 1997:121). Rituals within the worship service include the reading of the Law (often from the same passages of Scripture), confession of sins (often with the same repeated songs), reading from Scripture, sacraments and so forth (cf. Vos \& Pieterse 1997:122).

Verhoeven (1999:67) argues that the main intention of rituals is not to achieve something, but rather to express something. One 'does' rituals when you do not know what to do. The annual commemoration of the dead serves as example: it is not a rational purposive act, but rather 'een machteloos herkauwen van een onverteerbaar verleden' [a powerless rehashing of an indigestible past] and 'het ritmiseren van de eigen machteloosheid' [the rhythmising of their own powerlessness] (Verhoeven 1999:68). Rituals often express mankind's (the church's) own powerlessness in contrast to mankind's own rationality. In this sense, rituals represent another approach to the reality, where the focus is expressive rather than cognitive. Müller (1990:111) remarks in this regard: 'Die herhalende ritueel gee die versekering aan die deelnemers dat ' $n$ bepaalde ervaring, in hierdie geval 'n geloofservaring, 'n werklikheid was en weer kan terugkeer'. [The repetitive ritual gives the assurance to the participants that a specific experience, in this case an experience of faith, was a reality and can reoccur.]

Rituals of liturgy are often formulated in authoritative books like The Book of common prayer, the Missal or Handboek vir die erediens [Textbook for the worship service] (Wepener 2009:24). Wepener (2009:24) continues that 'the rituals as prescribed in these books can nonetheless sometimes become separated from the people who enact these rituals', thus implying that rituals can become outdated or removed from a specific culture or subculture (congregation). A ritual can never be 
seen apart from the people (or congregation) who conduct the ritual. Every ritual is closely connected to a situation and culture where the ritual is conducted (cf. Vos \& Pieterse 1997:121).

When does a certain act or conduct (or liturgical act) become a ritual? What makes a ritual a ritual as such? Grimes (1990:14; cf. Wepener 2009:34) formulates a list of ritual qualities; the latter includes characteristics like performed, formalised, repetitive, institutionalised, stereotyped, traditional, sentiment laden and deeply felt, multilayered, symbolic and so forth. Barnard (2002:19, Barnard 2000:5; cf. Barnard 1994:190, Lukken 1997:136) defines a ritual: 'Een ritueel is een complex van symbooltaal, symboolhandelingen en symbolen. Anders gezegd, een ritueel is een symbolische orde' [A ritual is a complex of language of symbols, symbolic acts and symbols. Said differently, a ritual is a symbolic order]. Wepener (2009) defines rituals as follows:

Rituals are often repeated, self-evident, symbolic actions, that are always interactive and corporeal, sometimes accompanied by texts and formulas, aimed at the transfer of values in the individual or the group, and of which the form and content are always culture, context and time bound, so that the involvement in the reality which is presented in the rituals remains dynamic.

(Wepener 2009:36)

Rituals could thus be summarised as often repeated actions with deeper symbolic meaning.

\section{Liturgical singing as ritual}

The question is whether liturgical singing could also be classified as a ritual in liturgy? In other words, can we say that liturgical singing is often repeated, self-evident, symbolic actions, sometimes accompanied by texts and formulas, aimed at the transfer of values in the individual or in the group? Gelineau (1978:83) remarks: 'Liturgical music has always had ritual status.' If it does and if music and songs do have ritual status, then the conversation on music and liturgical singing will have to be not only concerned with the musical style and genre, the words, the melody and the association of the song, but also with the ritual status, place and meaning of the song within a given congregation and the whole process of assigning meaning within that congregation. That would also imply that songs used in liturgical singing could not fully be evaluated apart from the congregation and context where they are sung; at least with regards to their symbolic and ritual meaning. That would also imply that there could be no objective study (alone) on a specific liturgical song, but that a certain song can only be studied in the context of the congregation where the song is sung, emphasising anew the role of (congregational and denominational) culture. As such, the same song or genre of music could have different meanings within different cultures or subcultures (congregations), as a result of their ritual and symbolic meaning.

Within Western culture with its shift from a hierarchicalbased culture to a network-based culture (cf. Barnard 2002:20), meaning is not assigned from above, but meaning is assigned by all participants on a continuous base. In the context of liturgy and ritual, this led to a unique situation where every participant in liturgy and ritual produces meaning for specific rituals. Thus, the meaning of rituals does not only differ from culture to culture or situation to situation; it also differs from individual to individual. Barnard (2002:25) mentions that the dynamic character of liturgical rituals always stands in tension with the view of liturgical rituals as a static entity. Rituals are context-bound and therefore subjected to change on a continuous base.

Barnard (2002:16, cf. Kubicki 1999:98-99) distinguishes two different perspectives with regards to symbols and rituals. The first perspective is that of symbols as representative, where a symbol represents something in another world or reality without making that reality present. The other perspective is that a symbol is presentative, making the world or reality it symbolises present in the present world. Most often, the Protestant churches tend to choose the first perspective, where emphasis is placed on the symbolic value of the ritual; the bread and wine in the Eucharist serves as example. In most Roman Catholic circles, the second perspective will be dominant, where symbol and ritual presents another reality within this one. God is thus present in bread and wine and the serving thereof.

But what about liturgical singing (= all singing within the worship service)? Is the repetitive act of liturgical singing only a symbol representing (or pointing to) another reality, or is the other reality present within congregational singing? Minatrea (2004:67, cf. Wepener 2008:206) states: 'Worship is not the learning about God; it is encountering God.' Thus, liturgical singing does not only remind about God, but it facilitates an encounter with God. If liturgical singing is a ritual like all the other rituals in liturgy, one will have to consider the current practice of liturgical singing within the DRC (referring in this article to the Dutch Reformed Church in South Africa, often referred to as the NG Kerk). Is liturgical singing learning and singing about God (representative) or is it encountering God (presentative)? Do the songs and music in the DRC only represent something of the other greater reality (God), or is God really present in liturgical singing? Can one say that representative liturgical singing will be more cognitive, factual and sober, whilst presentative singing will be more spontaneous, celebrative and ecstatic?

A musical practice that focuses only on the words (lyrics) and theology on the one hand and the musical genre on the other will not satisfy. In this regard, one must remember that within rituals the music is more important than the text (lyrics), and the meaning of the text is influenced and codetermined by the music (Vernooij 2002:102). Therefore, the music has to be very close to the specific culture or subculture where the ritual is conducted. For many years the playing of the organ had ritual meaning. The sound of the organ and the way the specific organist played the organ, as well as the genres of songs played conveyed meaning, often without spoken words. Certain songs had a fixed setting within the liturgy; one can just think about the songs after baptism; the songs 
played as part of the confession of sins and so on. Within contemporary culture in the DRC in South Africa, new rituals are born: the sound (ritual) of the band playing; the sound of a whole congregation singing a song like Oorwinningslied [Victory song]; the singing of a congregational anthem (Gemeentelied [Congregation song]); the atmosphere in singing a song of worship and so forth. It is argued here that certain genres and styles of music became synonymous with certain events (like youth services, Pentecostal services and so forth), mainly as a result of their ritual uses in these events.

Vernooij (2002:102) writes about music as a 'ritual teken' [ritual sign] where the music of the song itself plays a greater role than the text of a song. The meaning of the text is influenced and sometimes determined by the nature and tone of the music. Vernooij (2002:102) states that "in magischen rituelen "werkt" meer de klank dan de text.' [In mystical rituals, sound 'works' more than the text.] In this process, the expressive meaning of different forms of music is codetermined by tradition. He concludes that: 'Het zijn geluidsiconen, waarvan de symboolbetekenis met woorden amper kan worden geduid, maar in hun klanksignaal alomvattend spreken' [The icons are sound, the symbolic meaning of words can hardly be interpreted, but in their overall sound signal speaking.] (Vernooij 2002:103). The sound of the organ could have positive ritual meaning within one congregation, whilst the same sound may have no ritual meaning in another congregation. The same would be true of other instruments and genres.

Ritual does not only have an influence on music; music also has an influence on ritual. Ritual music needs to be familiar as well as repetitive. In this regard, ritual music or music as ritual can easily become passive music and a deadly (lifeless) routine. Wilson-Dickson (1992:30) states with regard to the Old Testament Temple, that 'in its latter days the music became part of a ritual which seems to have left little room for spontaneity. Instead, it acted more as a symbol.' In this context, trumpets symbolised God's power, whilst cantillation of Scripture symbolised the sanctity of Scripture. Wilson-Dickson (1992:30) states the importance of the two functions of music, namely to possess and to symbolise must be kept in balance.

\section{Liturgical singing as symbol}

Verhoeven (1999:119, cf. Barnard 1994:190) describes symbols as 'een samenvatting van betekenissen; het sluit de betekenissen van het tot symbool geworden ding in zich op en reserveert die' [A summary of meanings; it includes the meanings of that which became a symbol and reserves those meanings]. A symbol serves as a veil to a hidden reality, it protects the reality behind the symbol, but it also protects man. It unveils and it veils (Vos \& Pieterse 1997:123). As Verhoeven (1999:140) phrases: 'Het breekt de dodelijke straling van de werkelijkheid tot een gedempt licht' [It breaks the deadly radiation of reality into a subdued light]. Verhoeven (1999:140) sees art (music, philosophy, poetry and so forth) as well as cult, as veils that transform the veiled matter or object to a symbol, giving it maximum meaning. Symbols, in contrast to metaphors, do not have linguistic roots (Vos \& Pieterse 1997:123). Like dreams, they have multiple possible meanings; the possibilities are endless. An element of mystery remains.

Barnard (2000:10) refers to the evolution in church from a 'verbale en cerebrale liturgie naar een eredienst die alle zintuigen en kernvermogens aanspreekt' [Verbal and cerebral liturgy to a worship that appeals to all senses and core capabilities] and mentions 'cantorijen, stola's, antependia, beeldende kunstmanifestaties, dans, bloemschikking, kinderprojecten' [church choirs, stoles, antependia, visual art events, dance, flower arrangement, children's projects] (Barnard 2000:10) as examples of the the rich repertoire of symbols in Protestant tradition. In following Guardini (1923), he remarks that mankind must be skilled in symbols again. In this regard, the Protestant tradition needs to rediscover the power and impact of symbols.

There are various examples of symbols in a Reformed worship service (cf. Vos \& Pieterse 1997:12):

- the cross as symbol of the death of Jesus Christ

- the dove as symbol of the outpouring of the Spirit

- bread and wine as symbols of body and blood

- water as symbol of baptism and new life

- the table as symbol of the Eucharist

- the baptismal font as symbol of baptism

- the pulpit and pulpit Bible as symbol of the Word and the centrality of the Word.

Corporeality in the worship service is also part of the symbols in the worship service (cf. Barnard 1994:218-223, Vos \& Pieterse 1997:125-131).

It is argued here that liturgical music and singing are also symbols of the Christian church. The act of singing or the sound of the song already serves as a symbol of another reality. When watching the film Titanic, the sound of the violins playing Nearer my God to Thee recalled a whole other reality. Certain kinds of music are not only associated with certain churches or denominations, but often serve as a symbol of that church or denomination. The Genevan Psalter is a symbol of (Calvinistic) Reformation; often contemporary English praise-and-worship serves (mistakenly) as a symbol of Charismatic churches. Liturgical music is more than words and melody; it serves as a symbol to the listener and the participator (singer). It symbolises another reality. Therefore, the possible interpretations and meanings are endless. On the one hand, music does something in itself: it expresses, it praises, it proclaims and so forth. It is a form of art and thus, aesthetic (cf. Barnard 1994:356). On the other hand, music is also symbolic (Barnard 1994:228); it is part of something greater than itself. It is more than music and expression; it is part of a symbolic universe and has the power to signify and to symbolise.

Gino Stefani (Kubicki 1999:95, cf. Barnard 1994:177; Vos \& Pieterse 1997:124-125) concludes that liturgy is an ensemble of signs and 'liturgy is an action whose dominant value 
is situated in the order of signification'. Stefani further concludes that music (as part of liturgy) is one of the symbols in the ensemble of symbols and that music making could be described as a 'symbolizing activity' (cf. Barnard 1994:228).

Barnard (1994:191) mentions different schemes for classifying signs and symbols. The difference between a sign and a symbol is that the sign is iconic and, as an icon points to something beyond itself. A symbol also points to something beyond itself, but participates in the reality it points to. Polanyi \& Prosch (1975:70-73, Barnard 1994:186-189; cf. Kubicki 1999:98-99) illustrates the difference between sign and symbol as follows (Figure 1).

In figure 1, (S) represents the sign itself, whilst (F) signifies the matter the sign points to ('focal attention'). Thus, the sign points to the focal point. The (-ii) indicates that the (S) lacks interest, whilst (+ii) indicates that $(\mathrm{F})$ possesses interest. (S) has no meaning in itself and receives its meaning from $(\mathrm{F})$. (S) points to (F) and all the focus is on (F). There is a one-to-one relationship between the sign and the focal point.

On the other hand, Polanyi \& Prosch (1975:72) illustrates symbol as follows (Figure 2).

In figure 2, (S) has value in itself. The focus is on (S) and the observer (participator) is pulled into (S). The observers put themselves and their own existence into the subsidiary pointing or symbol (S). Kubicki (1999) explains:

A straight arrow cannot illustrate this dynamic. Therefore Polanyi devises an arrow loop in order to illustrate the way our perception of the focal object in symbolisation also:

carries us back toward and so provides us with a perceptual embodiment of those diffuse memories of our lives (i.e. of ourselves) which bore upon the focal object to begin with.

(Kubicki 1999:99)

The symbol thus starts and mediates a whole process of interaction between the symbol itself, the focal point and a person's whole life or existence. Lukken (1999) explains:

Bij het symbool krijgt het beperkte een oneindige ruimheid, iets bijna universeels. Het symbool is meerzinnig. Het heeft een grensoverschrijdende brugfunctie. Het verwijst naar een diepere werkelijkheid, een verdere horizon, een ruimer landschap. [In a symbol limited width becomes unlimited, almost universal. The symbol is more sensible. It has a bridge function. It refers to a deeper reality, a wider horizon, a broader landscape.]

(Lukken 1999:20)

If music acts as a sign rather than a symbol, then there is a one-to-one relation between music (musical properties or structures) and its outcome or effect. If music is a symbol, then it is more than the constellation of sounds with predictable referential properties. Nattiez emphasises the prominent role of the 'interpretant' in the symbolic dimension of music. He distinguishes three dimensions within the symbolic function: 'poietic', 'immanent' (neutral) and 'esthesic', where the immanent dimension interacts with the poietic and esthesic dimensions. Nattiez (1990:17) illustrates it as follows (Figure 3).

\section{$\stackrel{-i i}{\mathrm{~S}} \longrightarrow \stackrel{+i i}{\mathrm{~F}}$}

$S$, represents the sign itself; $F$, signifies the matter the sign points to. FIGURE 1: Signs.

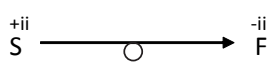

$S$, represents the sign itself; $F$, signifies the matter the sign points to.

FIGURE 2: Symbols.

\begin{tabular}{ccc|}
$\begin{array}{c}\text { Poietic Process } \\
\text { "Producer" } \longrightarrow \text { Trace } \longleftarrow \text { Esthesic Process } \\
\text { Receiver }\end{array}$ \\
\end{tabular}

FIGURE 3: Symbolic dimension of music.

'Trace' is the result of a very complex process (the poietic process) of creation, which includes form and content. On the other hand, 'trace' is the starting point for a complex process (esthesic process) of reception, where the receiver must reconstruct the message (trace). In this regard, Blacking (1982:19, cf. Kubicki 1999:114) stresses the importance of the context in the process of meaning. Not only the syntactic dimension (structure of music and text), but also the symantec dimension (context) contributes to the overall meaning of as song. Thus, the singer as well as the context of the singer contributes to the meaning of a song. Kubicki (1999:115) concludes that a song, as an exhibitive art form, is greater than the sum of its parts (text and melody).

With regards to rituals and symbols, one must thus remember that the meaning participants in the ritual assign to the ritual, as well as the way they take part in the ritual, are essential (Barnard 2000:5-6). In the present cultural context, meaning is not only assigned by the culture or community (congregation), but also and especially by the individual (member).

\section{Liturgical singing as ritual symbol}

Driver (1991) describes religious ritual as follows:

Religion's being danced out, sung out, sat in silence, or lined out liturgically, with ideation playing a second role, is not something confined to religion's early stages but is characteristic of religion as long as it is vital. This does not mean, of course, that ritual is mindless, nor anti-intellectual. It means that its form of intelligence is more similar to that of the arts than to conceptual theology, just as the intelligence of poetry is a different order from that of philosophy or literary criticism.

(Driver 1991:84; cf. Kubicki 1999:119)

Thus, ritual is closer connected to the arts than to cognitive or conceptual reasoning. Ritual, like art, is more exhibitive and therefore, in closer relation to the music than to the theological discourse. Rituals invite one to participate. The symbols within the ritual invite participation in the realities to which they point. Through the ritual and the symbol, one can experience the presence of God, forgiveness of sins and so forth.

Through the ritual of singing, singers are carried out of themselves. 'Ritual song as symbol puts us in touch with 
the power to which it points and opens us up to levels of reality which might otherwise be closed to us' (Kubicki 1999:122). Through liturgical music, the sacred is proclaimed, realised and celebrated (Kubicki 1999:122). As such, it is a prophetic symbol, transforming the lives of the participators and leading to new values. It has the power to influence the community of believers and lead to a fuller life in Christ. Thus, liturgical singing as ritual symbol creates a permanent attitude or deep emotion that ultimately forms and shapes the lives of the participators. As a result, the liturgical singing of a congregation forms that community over a period of time; they become what they sing.

Kubicki (1999:125-127) identifies and describes the music of the Taizé-community as a ritual symbol, with regards to the following:

- It involves all participators on physical level by singing, playing an instrument, moving with the rhythm or listening.

- The physical participation leads to a deeper participation in the presence of God. In the singing, a person's whole life is brought in an encounter with God.

- In the singing, the community of believers is experienced.

- Through singing, Christian attitudes like faith, trust, praise, love, thanksgiving, et cetera, are expressed.

- In the esthesic process, each participator is involved by assigning meaning through composing, singing, playing, listening, interpreting and so forth. All participators are involved in the process of generating meaning.

- In the generation of meaning (the esthesic process), the experience-domain (context) of each participator plays a great role.

The same would be true of congregational singing in most DRC congregations. In the process of congregational singing, all participators are involved in the singing through the act of singing, playing an instrument, closing eyes, lifting up hands, sitting, standing, moving to the music or just listening actively to the music and singing. This participation often leads to an awareness of God, an awareness of his presence and often an encounter with him. In this whole act of singing with fellow-believers, the unity with the body Christ is experienced. Just like in Taizé, Christian attitudes like faith, trust, praise, love, thanksgiving and so forth are expressed in and through liturgical singing. All members of the congregation who participate in die music and singing are involved in assigning meaning through singing and interpreting. The context of each participant plays a major role in this process. In other words, whilst all members of the congregation sing the same text (lyrics) and melody, they experience the encounter with God differently. Their encounter with God is much more than the combination of the meaning of text and melody.

\section{Implications for liturgical singing}

Liturgical singing is much more than the combination of text, melody and presentation. Liturgical singing is a ritual symbol that does not only point to another reality, but mediates and facilitates an encounter in or with the other reality.
Therefore, liturgical singing is much more than creating atmosphere; singing whilst the children leave the building; doing something whilst infants are brought to the baptismal font and so forth. The ultimate purpose of liturgical singing is an encounter with the other reality, namely the Father, Son and Holy Spirit. This encounter remains the initiative, work and grace of God. Liturgical singing is a cultural act and meaning is attributed within the cultural act of singing. Therefore, the meaning of a song is not only determined by the immanent meaning of the text (lyrics), but also by the meaning attributed by the congregation. Meaning could thus greatly differ from congregation to congregation. Meaning is not only found in the lyrics of the song, but also in the act (ritual) of singing. Often the meaning immanent in a text will differ from the meaning a congregation assigns to a song.

Rituals are closely connected to culture and give expression to common identity. Liturgical singing within a certain congregation thus gives expression to the unique identity of a given congregation. Like all other rituals, liturgical singing will differ from culture to culture, or congregation to congregation. This would explain why members of a given congregation would sing, accompany and respond to a certain kind of music the way they do. This may differ greatly from congregation to congregation; in the same way the ritual value of a song differs from congregation to congregation, as a result of the close relationship between liturgy and culture.

Just as the rituals prescribed in liturgical books can sometimes become separated from the people who enact these rituals, prescribed singing rituals (liturgical singing) could become separated from the people (members of a congregation) who participate in the singing, leading to deadly routine; the latter must be distinguished from a living ritual. Sometimes a song that had ritual meaning within a certain culture could become meaningless within new or other cultures; or it could become meaningless within the same congregation in course of time. It is argued here that songs, melodies, lyrics, genres of music or accompaniments of music could become separated from the 21st century congregations who sing those songs.

Within the ritual, the focus is more on the music (beauty and effect of a song) than on the lyrics. Sometimes the most beautiful (and theological correct) lyrics will not become part of the living ritual within a given congregation, because the music (melody or accompaniment) did not succeed in receiving ritual status. This could be one of the reasons why so many Psalms in the Liedboek van die Kerk [Songbook of the church] (cf. Van Rooy 2008) are not sung in worship services.

Rituals, like culture, are not static but in a continuous process of change. Therefore, new rituals with new (or older) forms of music were born continuously throughout the history of the church; new rituals of liturgical singing are born in every era. With regards to church singing, this could imply not only new songs (lyrics), but also new genres of songs, new accompaniments of songs, new presentations as well as a new role of liturgical singing. New rituals (including new liturgical music) must be born continuously. The church must always be open to the birth of new rituals. 


\section{Contemporary examples}

The meaning of a song is influenced and codetermined by the following: the meaning of the text, the interpreted meaning of the text, the effect of the music and melody, associated meaning, symbolic meaning and ritual meaning. Three examples will now be discussed briefly, in order to illustrate the assigning of meaning through symbol and ritual.

\section{Ons Vader [Our Father] (Song 266 in Liedboek van die Kerk) [Songbook of the church]}

The text of this song is based on the Our Father prayer, where Jesus taught his disciples to pray (Mt 6:19-13). The Afrikaans version was published in the Halleluja (1903 \& 1951) and thereafter included in the Psalms en Gesange [Psalms and hymns] (1978) and in the Liedboek van die Kerk [Songbook of the church] (2001). The melody was composed by Luther Emerson (1820-1915). In essence, the text of the song is a prayer, worshiping God for who he is, praying for his Kingdom to come, asking for daily bread, forgiveness of sins and so forth. This song is not only representative in that it reminds us about God who cares and provides; it is a prayer itself facilitating an encounter with God, where the singer asks for the coming of the Kingdom, daily bread, forgiveness of sins, and so forth. It does not only remind us about prayer; it is prayer. After singing (praying) this prayer for many years within a certain congregation, the meaning of the prayer is much broader than the combination of text and lyrics. It recalls certain events; times of trails when the prayer was sung (prayed); difficult times when God intervened and provided bread and so on. In a certain sense, it recalls God's provision, care, love and Kingdom. One can say that the individual's whole life is brought before God in the act of singing this song and ultimately praying this prayer. Symbol and ritual contribute to meaning, and the individuals who sing this song, contribute meaning from their own life. Every individual will recall and revisit different events and experiences. But the opposite is also true: as a result of various reasons (routine, bad memories, associations and the like), this song (like any other song) could lose its symbolic and ritual value within a certain congregation; it can become a deadly routine in itself. It could be sung every Sunday at the end of the worship service without facilitating an encounter with God. Therefore, new rituals need to be born continuously.

\section{Oorwinningslied [Victory song] (Afrikaans contrafact)}

A recent study (Calitz 2011) in the DRC presbytery of Potchefstroom-Mooirivier indicated that all congregations sing the Oorwinningslied as part of their repertoire for the worship service, although this song is not included in the official hymnal. It is even more noteworthy that congregations who only sing songs from the official hymnal of the church (Liedboek van die Kerk [Songbook of the church]), add the Oorwinningslied to their repertoire of songs. Oorwinningslied could be described as a contemporary contrafact set to the music and melody of The song of the republic. The Afrikaans text was written by Piet Smit, a contemporary Afrikaans gospel singer. The song was recently included in FLAM ${ }^{1}$, but was sung long before its inclusion in FLAM. Although some musicologists see this song as poor partly as a result of its association to the military and war, the value of this song can hardly be over-estimated. One can hardly imagine a celebration in a present-day congregation without including Oorwinningslied somewhere in liturgy. In spite of its military associations, this song succeeded in becoming part of the living ritual in most DRC congregations (including congregations with primarily older people). The value and meaning of this song are much more than the immanent meaning of the text. It symbolises God's victory; God's Word and God's triumph. In the ritual of singing this song, the singer is lifted up and for a moment experiences a foretaste of God's victory. Without a doubt it is one of the songs that succeeded in becoming a living ritual. In the same way, a song like Nader my God by $U$ [Nearer my God to Thee] (Die Halleluja 290) became part of the living ritual of congregations in times of sorrow or grief.

\section{Congregational anthem}

Like countries and schools, congregations often have congregational anthems or songs written for specific occasions or happenings (often in the form of a contrafact) in a congregation. These songs or anthems were often written by individual members sharing the life and story of the congregation. From musicological or linguistic perspective, these songs could be 'poor' or 'of lower standard', but for some reason they are greatly loved and treasured in a specific congregation. What could be the reason for this? Often these songs have enormous symbolic and ritual value. They symbolise certain events (often interventions from God) in the life of the congregation. Through their repetitive use at all major events in a congregation, they become part of the living ritual in a congregation. The story of the congregation, as well as the story of the individual believer is recalled in the ritual of singing this song. The song becomes more than text and melody; it becomes ritual. In ritual the music is more important than the text. All meaning is not immanent in the text; meaning is attributed by the individual or congregation who sings this song on a continuous base.

\section{Conclusion}

Liturgical singing is more than text and melody. It is part of the repertoire of symbols and rituals within a congregation, representing and presenting another reality. It facilitates

1. The birth of FLAM in 2002 is described and motivated as follows (http://www.flam. co.za, 10 Aug 2010): 'In 2002, nadat die Liedboek die kerk in SA getref het, was daar ' $n$ beduidende groot groep lidmate wat aangetoon het dat die Liedboek té min, té laat was. Die grootste klagte was dat daar nie genoeg kontemporêre ('band') musiek was nie en dat die jeug (wat die kinders en veral die hoërskool- en naskoolse jongmense insluit) weer eens aan die kortste end getrek het. By die daaropvolgende Algemene Sinode (AS) van die Ned Geref Kerk het die AS toe ' $n$ taakspan in die lewe geroep wat ' $\mathrm{k}$ meganisme moes skep waardeur die kerk nuwe, Afrikaanse kontemporêre kerkmusiek op ' $\mathrm{n}$ voortdurende basis kon invoer.' [In 2002, after the Liedboek hit the church in SA, there was a significantly large group of congregants who indicated that the Liedboek was too little, too late. The biggest complaint was who indicated that the Liedboek was too little, too late. The biggest complaint was that there was not enough contemporary (band) music and that the youth (which included the children and especially the high school students and young people after school) once again had the short end of the stick. At the following General Synod (GS) of the DRC, the GS then called a taskforce into being who had to create a mechanism whereby the church could import new, Afrikaans church music on a continuous basis.] Thus, FLAM could be described as a commission within the DRC with the mission of creating, selecting and approving new contemporary music. 
an encounter with God and fellow believers. It is more than just a song: it is praise, prayer, worship, confession, proclamation and wonder. Therefore, new rituals need to be born continuously within the local congregation.

\section{References}

Barnard, A.C., 1994, In die kragveld van die Woord en die Gees [In the force field of the Word and the Spirit], Etoile, Voortrekkerhoogte.

Barnard, M., 2002, 'Tendensen in de dynamiek van cultus en cultuur: perspectieven in de liturgiewetenschap' [Trends in the dynamics of cults and culture: Perspectives in liturgical studies], in M. Barnard \& N. Schuman (reds), Nieuwe wegen in de liturgie pp. 11-27, Meinema, Zoetermeer

Barnard, M., 2000, Liturgiek als wetenschap van christelijke riten en symbolen [Liturgy as the science of Christian rites and symbols], Vossiuspers, Amsterdam.

Barnard, M. \& Schuman, N. (reds), 2002, Nieuwe wegen in de liturgie. Die weg van de liturgie - een vervolg [New ways in the liturgy. The way of the liturgy - a sequel], Meinema, Zoetermeer.

Blacking, J., 1982, 'The Structure of Musical Discourse: The problem of the Song Text', Yearbook for Traditional Music 14, 15-23. doi:10.2307/768068

Calitz, C.J., 2011, 'The free song (hymn) as a means of expression of the spirituality of the local congregation with specific focus on the situation of the Dutch Reformed Church in South-Africa', PhD-thesis, Dept. of Theology, University of Pretoria.

Driver, T.F., 1991, The Magic of Ritual: Our Need for Liberating Rites that transform our Lives and Our Communities, Harper Collins Publishers, San Francisco, CA.

Gelineau, J., 1978, The liturgy today and tomorrow, transl. D. Livingstone, Darton, Longman \& Todd, London, UK.

Grimes, R.L., 1990, Ritual Criticism. Case Studies in its Practice. Essays on its Theory, University of South Carolina Press, Columbia.

Kubicki, J.M., 1999, Liturgical music as ritual symbol. A case study of Jacques Berthier's Taizé music, Peeters, Leuven.

Lukken, G., 1999, Rituelen in overvloed. Een kritische bezinning op de plaats en de gestalte van het christelijk ritueel in onze cultuur [Rituals abound. A critical reflection on the position and form of the Christian ritual in our culture], Gooi \& Sticht, Baarn.
Lukken, G., 1997, 'Liturgiewetenschappeljk onderzoek in culturele context. Methodische verhelderingen en vragen' [Liturgical scientific research in cultural context. Methodological clarifications and questions], Jaarboek voor liturgie onderzoek 13, 135-148.

Minatrea, M., 2004, 'Missional Practice Number Four. Rewrite Worship every week', in M. Minatrea (ed.), Shaped by God's heart. The Passion and Practices of Missional Churches, pp. 65-76, Jossey-Bass, San Francisco, CA.

Müller, J., 1990, 'Vernuwing in die erediens'[Renewal in the worship service], in A.J. Smuts, C.J.A. Vos \& M. Nel (reds), pp. 106-120.

Müller, J., 1987, 'Vastheid, variasie en kreatiwiteit in die liturgie' [Fastness, variation and creativity in the liturgie], in A.J.Smuts, (red.), Perspektiewe op die erediens [Perspectives on the worship service], pp. 1-42, Praktiese Teologie in Suid Afrika 3,

Nattiez, J., 1990, Music and Discourse: Toward a Semiology of Music, transl. C. Abbate, Princeton University Press, Princeton, NJ.

Polanyi, M. \& Prosch, H., 1975, Meaning, The University of Chicago Press, Chicago, IL.

Smuts, A.J., Vos, C.J.A. \& Nel, M. (reds), 1990, In gesprek oor die Erediens [In conversation about the worship service], NG Kerkboekhandel Bpk., Pretoria.

Van Rooy, J.H., 2008, 'Die Psalmboek 2003 as kommmunikasiemiddel in die liturgie van die erediens in die Gereformeerde kerke in Suid-Afrika: ' $n$ Himnologiese studie' [The Psalmbook 2003 as communicator in the liturgy of the worship service in the Reformed churches in South Africa: A hymnological study], PhD-thesis, North-West University, Potchefstroom.

Verhoeven, C., 1999, Het alziend oog [The all-seeing eye], Uitgeverij, Damon.

Vernooij, A., 2002, 'Muziek en liturgie' [Music and liturgy], in M. Barnard \& N. Schuman (reds), Nieuwe wegen in de liturgie. Die weg van de liturgie - een vervolg [New ways in the liturgy. The way of the liturgy - a sequel] pp. 95-113, Meinema, Zoetermeer.

Vos, C.J.A. \& Pieterse, H.J.C., 1997, Hoe lieflik is U woning (Studies in Praktiese Teologie) [How lovely is Thy dwelling (Studies in practical theology)], RGN uitgewery, Pretoria.

Wepener, C.J., 2009, From Fast to Feast. A ritual-liturgical exploration of reconciliation in South African cultural contexts, Leuven-Paris-Dudley, Peeters, MA.

Wepener, C.J., 2008, 'Towards a missional liturgy', NGTT 49 (1\&2), 206-219.

Wilson-Dickson, A., 1992, A Brief History of Christian Music, Lion Publishing, Oxford, UK. 